\title{
Adaptation to Exercise Following Cardiac Transplantation
}

\author{
A na Fátima Salles, Japy A ngelini O liveira Fo
}

São Paulo, SP - Brazil

Cardiac transplantation has been the treatment of choice for patients with terminal cardiac insufficiency, increasing survival time by more than $80 \%$ in the first year ${ }^{1}$ and by more than $50 \%$ over ten years ${ }^{2}$. Following cardiac transplantation, the quality of life improves considerably, and many transplanted patients return to work becoming reintegrated into the community ${ }^{3}$. During regular activity, transplanted subjects have shown physical conditioning similar to that of healthy individuals ${ }^{4-7}$. Starling's axiom, "today's physiology will be tomorrow's medicine" ${ }^{8}$, emphasizes the need for knowledge about post-transplantation cardiovascular adaptations, to serve as the basis for clinical treatment and rehabilitation. The present article has the aim of discussing the state-of -the-art of this subject.

Aerobic capacity - Aerobic capacity is the total amount of $\mathrm{O}_{2}$ capable of being metabolized by an organism. Aerobic potency is the amount of $\mathrm{O}_{2}$ consumed per unit of time $\left(\mathrm{VO}_{2}\right)$. Maximal $\mathrm{O}_{2}$ consumption $\left(\mathrm{VO}_{2}\right.$ max. ) or maximal aerobic potency is the maximum $\mathrm{VO}_{2}$ obtained in an endurance (of progressive loads) test, in which $\mathrm{VO}_{2}$ reaches a maximal value without additional increase due to an additional work load. In tests in which the patient does not reach maximum oxygen consumption, as frequently occurs in cardiopathy patients and transplanted subjects, peak $\mathrm{VO}_{2}$ is defined as the highest value of $\mathrm{VO}_{2}$ obtained. Following cardiac transplantation, patients progress with a reduction of peak $\mathrm{VO}_{2}{ }^{9-15}$ of $30-50 \%{ }^{16-22}$. In our study ${ }^{6,7}$, deficits were $32.4 \%$ and $25.7 \%$ at peak exercise and at the anaerobic threshold, respectively. Marzo et al ${ }^{18}$ found a $35 \%$ reduction in the absolute values of the anaerobic threshold. Degré et $\mathrm{al}^{23}$ reported an early and intense accumulation of lactate during exercise, attributed to increased production in active tissues and reduced clearance secondary to decreased blood flow in the liver and other inactive tissues. In our study ${ }^{7}$, $\mathrm{VO}_{2}$ in light to moderate submaximal exercise ( 40 watt load) below the anaerobic threshold was 12.34 and $12.38 \mathrm{ml} / \mathrm{kg} /$ min, in transplanted and healthy subjects, respectively, without significant differences between these groups. Meyer et al ${ }^{24}$, working with a load of 50 watts, reported a $\mathrm{VO}_{2}$ of

Universidade Federal de São Paulo - Escola Paulista de Medicina Mailing address: Ana Fátima Salles - Rua Cantagalo, 229 - 03319-000 São Paulo, SP, Brazil
$0.96 \pm 0.1$ and $0.95 \pm 0.08 \mathrm{~L} / \mathrm{min}^{-1}$ in transplanted and control subjects, respectively.

The reduction of peak $\mathrm{VO}_{2}$ is due to multiple factors, both central and peripheral. Chronotropic incompetence and alteration in diastolic function are central factors ${ }^{21,22,25,26}$. At the peripheral level, reduction of peripheral oxygen extraction occurs ${ }^{17,21,22,27-29}$. An exaggerated neuroendocrine respon$\mathrm{se}^{19}$ and reduced capacity of pulmonary diffusion ${ }^{20,30}$-also seem to be involved in decreased tolerance to exercise.

Heart Rate-Heart rate values at rest have been observed to be higher in transplanted compared with healthy individuals due to the absence of parasympathetic innervation and corresponding to the intrinsic frequency of the sinus node ${ }^{17,23,31-35}$. The resting heart rate of transplanted subjects is 14 to $15 \mathrm{bpm}$ above that of their controls paired by sex and age ${ }^{36}$, and 0 to $26 \mathrm{bpm}$ above controls paired by sex, age, weight and height ${ }^{6,7}$. At the beginning of exercise, the heart rate rises slowly with a pattern of a depressed curve relative to that in healthy individuals; frequency acceleration is restricted to about one third of that of healthy individuals ${ }^{37}$. It has been reported that this pattern persists for 10 years following transplantation ${ }^{38}$. Due to posttransplantation denervation, heart rate is controlled by the humoral route dependent of the levels of catecholamines released from the suprarenal gland ${ }^{9,10}$. Nevertheless, submaximal heart rate remains significantly higher in transplanted patients relative to controls up to levels of 50\% of maximal exercise (fig. 1) ${ }^{39}$. Such higher levels during submaximal exercise could reflect increased plasma levels of catecholamines, increased density of beta-receptors ${ }^{40}$, as well as an intrinsic positive chronotropic effect at the pacemaker induced by venous return ${ }^{41-43}$. At peak exercise, the heart rate in transplanted individuals is 20 to $25 \%$ lower than that in healthy controls. This chronotropic deficiency is attributed to the absence of sympathetic innervation of the sinus node ${ }^{35}$ Persistence of chronotropic incompetence has been observed 2 to 6 years following cardiac transplantation ${ }^{22}$. Later transplanted patients have better chronotropic responses than recent ones ${ }^{44}$. The improved chronotropic response during exercise of some patients six months following cardiac transplantation suggests sympathetic efferent reinnervation ${ }^{44}$. Evidence of late reinnervation in some transplanted subjects has been demonstrated immunochemically ${ }^{45}$. Also, the reappearance of the circadian rhythm of heart rate in the late cardiac posttransplant follow-up seems 


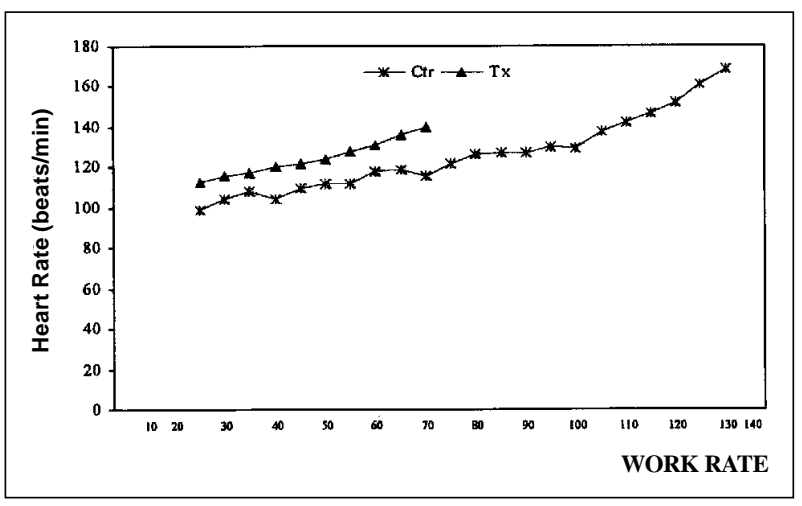

Fig. 1 - Variation in heart rate during an exercise test of a 44- year-old male patient five months following cardiac transplantation due to dilated myocardiopathy. Ctr: healthy control; Tx; transplanted patient; bpm: beats per $\min ^{6}$.

to reinforce the hypothesis of partial reinnervation in some transplanted patients ${ }^{46-48}$. In the early phase of cardiac postransplantation, cardiac frequency keeps increasing during the first two minutes of the phase of recovery from exercise, despite the immediate decrease of circulating catecholamines ${ }^{23,34}$. This delayed deceleration is possibly due to an increased sensitivity of the denervated heart to catecholamines ${ }^{49}$ (fig.2). Individuals examined from one to ten years after transplantation had an immediately decreased heart rate in the first minute of recovery ${ }^{23}$. Kavanagh and Yacoub reported a reduction in resting heart rate and increased peak cardiac frequency after two years of physical training. However, resting heart rate remained higher and peak heart rate lower when compared to with that in controls. The mechanism responsible for the adaptation of heart rate following conditioning has not been clarified ${ }^{49}$.

Ventricular function - Reduction in systolic volume during rest and exercise has been reported in transplanted compared with healthy individuals. Kao et al ${ }^{22}$ submitted transplanted patients to an invasive exercise test in associated with oxygen consumption and radioisotope effort ventriculography, obtaining direct measurements of the ejection

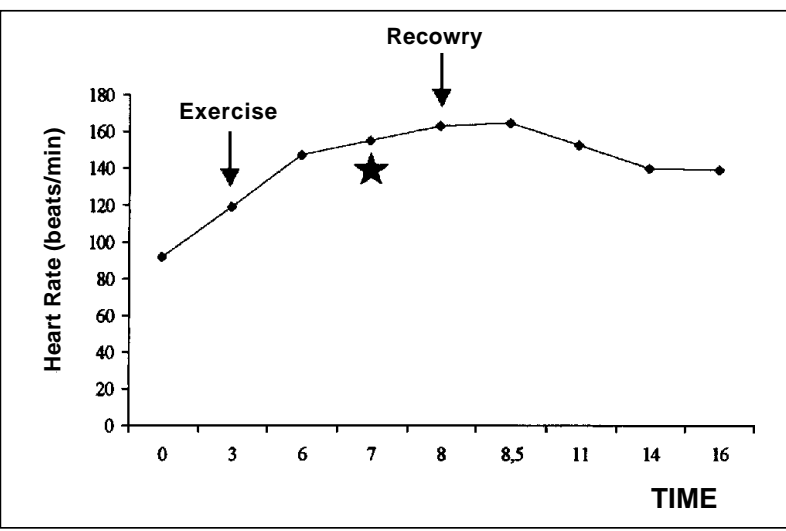

Fig. 2 - Pulmonary ventilation during an exercise test in a 38-year-old male patient, 47 months following cardiac transplantation due to dilated myocardiopathy. Ctr: healthy control; Tx; transplanted patient; VE BTPS- pulmonary ventilation at body temperature and pressure and under saturation with steam ${ }^{6}$. fraction and ventricular volume. They reported lower systolic volume in transplanted individuals during rest in the orthostatic position, submaximal and maximal exercise, and related this finding to reduced final diastolic volume secondary to the alteration of diastolic function ${ }^{21}$. They demonstrated that the relationship between pulmonary capillary pressure and the index of final diastolic volume (PCP/IVDf) had higher values in transplanted subjects during rest and during exercise, indicating decreased ventricular complacency ${ }^{21}$. Martin et al ${ }^{26}$ found similar results in supine, and orthostatic resting, and at $20 \%$ maxímal oxygen consumption in transplanted subjectes. The pathogenesis of diastolic dysfunction has not been clarified. Preservation techniques, length of time of graft ischemia, occurrence of rejection, systemic arterial hypertension, arterial coronary disease and the use of cyclosporine have been suggested as etiological factors ${ }^{21,26}$.

During exercise, increased systolic volume, secondary to the Frank-Starling mechanism and elevations in heart rate and contractility, secondary to the release of catecholamines by the adrenal glands, occur sequentially in transplanted patients; the Frank-Starling mechanism is apparent in the initial phase. In the healthy heart these events occur simultaneously ${ }^{50}$. Despite the chronotropic incompetence at peak exercise, transplanted subjects make less use of the Frank-Starling mechanism to increase systolic volume than do healthy individuals, due to diastolic dysfunction ${ }^{21}$. Follow-up evaluation of these patients did not show improvement of diastolic function ${ }^{22}$.

The evaluation of systolic function via ejection fraction has shown conflicting results. The ejection fraction of transplanted patients has values similar to those in healthy individuals during rest and exercise in the orthostatic position 8.5 \pm 3.9 months following transplantation ${ }^{21}$. Follow-up evaluation of these patients (2-6 years following transplantation) showed ejection fraction values significantly higher during rest, and similar to normal values during exercise ${ }^{22}$. Pflufelder et al ${ }^{51}$ analyzed ejection fraction 11 months following transplantation and found values similar to those in healthy patients, both at rest and during supine exercise. Tischler et $\mathrm{al}^{52}$ in a serial evaluation of ventricular function, found normal ejection fraction values after one month and after one and four years following transplantation.

During the first year following transplantation, the cardiac index reaches significantly lower values in transplanted patients at peak exercise, mainly because of a chronotropic deficit; in submaximal exercise, this occurs at the cost of systolic volume ${ }^{17,21}$. Two to six years following transplantation, cardiac index values remain significantly below normal in such patients ${ }^{22}$.

Peripheral oxygen extraction -Peripheral factors play a relevant role in functional limitation after cardiac transplantation. Bussières et al ${ }^{53}$ demonstrated an inverse correlation ( $\mathrm{p}<0.001$ ) between posttransplantation oxygen arteriovenous difference $\left(\mathrm{D}(\mathrm{a}-\mathrm{v}) \mathrm{O}_{2}\right)$ and functional aerobic 
deficit(FAI: max.pred. $\mathrm{VO}_{2}$ - peak $\mathrm{VO}_{2} /$ max.pred. $\mathrm{VO}_{2}$ x 100 ), $(\mathrm{r}=-0.66)$. Savin et al ${ }^{54}$ reported a $\mathrm{D}(\mathrm{a}-\mathrm{v}) \mathrm{O}_{2}$ significantly lower than that of healthy controls at peak exercise. At submaximal exercise levels, a tendency towards higher values of $\mathrm{D}(\mathrm{a}-\mathrm{v}) \mathrm{O}_{2}$ was found and attributed to a compensatory mechanism in view of the reduction of cardiac output. Kao et al ${ }^{21}$ reported $\mathrm{D}(\mathrm{a}-\mathrm{v}) \mathrm{O}_{2}$ values significantly reduced at peak exercise but similar to control values at rest or submaximal exercise. Mettauer et al ${ }^{55}$ described similar results. The nature of these abnormalities has not been clarified. Irreversible alterations due to congestive cardiac insufficiency, physical deconditioning and prolonged corticoid treatment may possibly be interfering with these results ${ }^{56-60}$.

Vascular resistance - Transplanted patients progress with a 45 to $92 \%$ incidence of arterial hypertension (International Registry of Cardiac Transplantation) ${ }^{61}$. Bortolotto et al ${ }^{62}$ observed arterial hypertension in $58.5 \%$ of patients 30 days following surgery, increasing to $93 \%$ after one year. Despite high blood pressure levels during rest, the patients' mean arterial pressure reached values significantly lower than those of healthy controls at peak exercise ${ }^{21}$. In our study, we found significantly higher levels of diastolic arterial pressure at rest and at peak exercise in transplanted subjects relative to that in controls, and no differences of systolic arterial pressure between groups ${ }^{6,7}$. The etiology of this complication seems to be multifactorial, having as a common final route the elevation of systemic vascular resistance ${ }^{63-67}$. The reason for the attenuated pressure response at peak exercise has not been clarified ${ }^{18}$.

In view of the high incidence of posttransplantation arterial hypertension, comparative studies of cardiac transplants should include subgroups of apparently healthy and hypertensive patients. The majority of studies relating to physiological adaptation of transplanted patients to exercise rely on controls of apparently healthy individuals.

In transplanted subjects, levels of systemic vascular resistance relative to apparently healthy controls are persistently elevated both at rest and at exercise; however, resting values undergo marked reduction during exercise, a behavior similar to that of healthy individuals ${ }^{21,26}$. Bocchi et al ${ }^{68}$ noted a fall in systemic vascular resistance during exercise in the supine position. Raised systemic vascular resistance could be attributed to the persistence of a pre-transplantation abnormality, secondary to congestive cardiac insufficiency (physical deconditioning, deficient mechanisms of peripheral vasodilatation due to $\mathrm{Na}^{+}$and $\mathrm{H}_{2} 0$ retention) and special posttransplantation conditions (physical deconditioning, use of cyclosporine and neuroendocrine abnormalities) ${ }^{21}$.

Following transplantation, mean pulmonary arterial pressure is significantly higher at rest and during exercise. Similarly to that in healthy controls, values rise during the effort test ${ }^{21,26}$. Pulmonary vascular resistance is significantly elevated in transplanted patients at rest and during exercise and decreases during effort in the same manner as in healthy individuals. These findings have been associated with the irreversibility of vascular pulmonary alterations due to chronically elevated pressure in the pulmonary artery ${ }^{21.26}$.

Pulmonary ventilation - Several studies have pointed to the excessive ventilation work of the transplanted patient, characterized by higher values of the ventilatory equivalents for $\mathrm{O}_{2}$ and $\mathrm{CO}_{2}$ at submaximal exercise ${ }^{18,19,23}$. Pulmonary ventilation at peak exercise is significantly reduced in transplanted subjects relative to that in healthy controls $6,7,11,18,19,26$ (fig.3). However, when analyzing values of pulmonary ventilation, ventilatory equivalent for oxygen, ventilatory equivalent for carbon dioxide at the anaerobic threshold and at the $40 \mathrm{~W}$ potency, no significant differences between healthy and transplanted patients are apparent ${ }^{7}$. The mechanism responsible for the excessive ventilation response in transplanted individuals has not been clarified. Pope et al and Savin et al attributed this response to the attenuated cardiac output curve during exercise secondary to cardiac denervation with an altered ventilation/perfusion ratio and an increased physiological dead space ${ }^{9,54}$. Marzo et al ${ }^{18} \mathrm{de}-$ monstrated that in transplanted patients, the ventilatory equivalent for carbon dioxide at rest was not significantly different in relation to that in controls. In this situation cardiac output was similar to the normal. Another explanation for the excessive ventilatory response could be muscular respiratory dysfunction consequent to hypoperfusion and muscular fatigue ${ }^{67,70}$. Kavanagh et al ${ }^{71}$ reported significant improvement in the respiratory response during exercise following physical training.

Neuroendocrine response - An exaggerated neuroendocrine response in transplanted vs control subjects who performed the same relative levels of exercise has been reported. Braith et al ${ }^{19}$ found neuroendocrine hyperactivity at rest characterized by significantly higher values of plasma renin and atrial natriuretic peptide. At 70 and $100 \%$ peak $\mathrm{VO}_{2}$, plasma renin activity and estimates of atrial natriuretic peptide, vasopressin and norepinephrine were significantly elevated in the transplanted group ${ }^{19}$. The neuroendocrine profile of the transplanted patients could be attributed to the

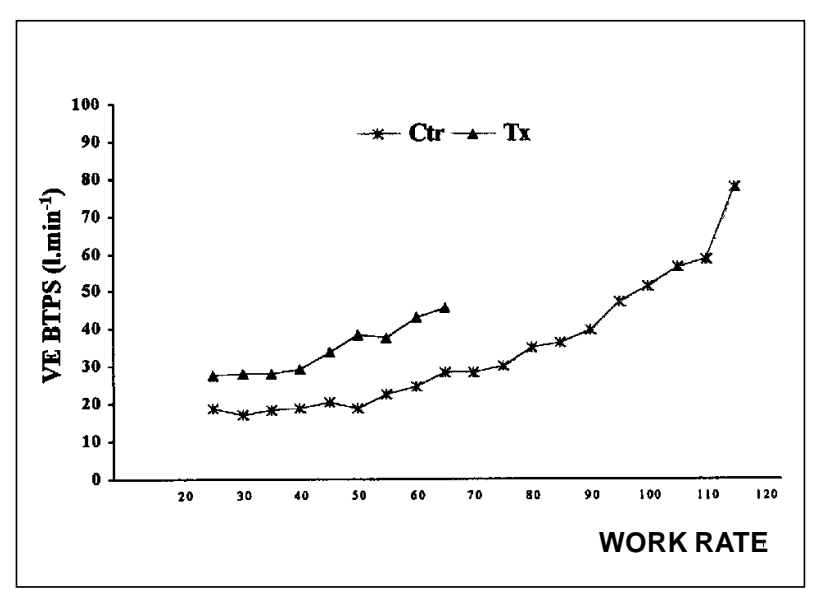

Fig. 3 - Variation in heart rate during an exercise test of a 30-year-old female patient 16 months following cardiac transplantation due to dilated myocardiopathy. The exercise peak is indicated by *; bpm: beats per min. 
use of cyclosporine ${ }^{72,73}$ and hypertensive medication ${ }^{74}$, skeletal muscle deconditioning ${ }^{28,75}$ and cardiac denervation ${ }^{19}$. Cardiac denervation causes loss of the afferent stimulation of atrial stretch receptors due to disconnection of the heart from the brain, with consequent reflex inhibition of neurohormones ${ }^{19}$. Chronic neuroendocrine hyperactivity has been associated with the incidence and seriousness of arterial hypertension following cardiac transplantation ${ }^{19}$.

Exercise test - Relative to cinecoronariography, the conventional exercise test shows poor postcardiac transplantation performance in the detection of coronary artery disease. Sensitivity and positive prediction values were respectively $21 \%$ and $21 \%$ (Smart et al $^{76}$ ) and $0 \%$ and $0 \%$ (Ehrman et al ${ }^{77}$ ). The detection and evaluation of the seriousness of coronary artery disease by myocardial scintilography has been considered class IIB following cardiac transplantation due to reduced sensitivity and specificity ${ }^{78}$. Ehrman et al ${ }^{77}$ attribute the low sensitivity of the exercise test for the detection of myocardial ischemia to the low cardiac frequency reached at peak exercise and to the high prevalence of complete right branch blockade. Rodney and Johnson ${ }^{79}$ reported the diffuse nature of coronary artery disease at grafting as the most probable cause of the low sensitivity of studies of myocardial perfusion.

The exercise test is used in the prescription of exercise in supervised rehabilitation programs. Cardiac frequency and arterial pressure responses during effort of transplanted persons are often modest, and other parameters like perceived effort are better for the estimation of the degree of the exercise. Exercise test protocols must have increments of lower intensity to give the denervated heart time to respond to circulatory catecholamines ${ }^{80}$. Steady state protocols are more appropriate because they permit better hormonal and metabolic adaptation. The $\mathrm{VO}_{2}$ peak is not altered with this type of protocol ${ }^{81}$. Modified forms of the Bruce or Naughton ${ }^{49}$ protocols attaining peak effort in $8-10 \mathrm{~min}$ by 1 to 2 MET increments have been used. In the cycloergometer, increments of 50 or $100 \mathrm{Kpm} / \mathrm{min}$ at each minute have been used $^{49}$. We have used increasing load protocols with increments of 5 watts/minute after an initial stage of 3 min at 25 $\mathrm{W}$, maintaining an average of 50 rotations per $\min ^{6,7}$. The electrocardiogram is continuously monitored, and the arterial pressure is measured every two min, at the peak of the exercise and during recovery. Measurements of $\mathrm{VE}, \mathrm{VO}_{2}$,
$\mathrm{VCO}_{2}, \mathrm{RER}, \mathrm{PEO}_{2}$ and $\mathrm{PECO}_{2}$ are made in expired air at each respiration. Borg's scale of perceived effort is used at every stage ${ }^{49}$. Special attention should be paid to symptoms of dyspnea, dizziness, weakness and electrocardiographic signs, in view of the incapacity of transplanted patients to manifest angina pectoris.

Cardiac rehabilitation - Long periods of perioperation inactivity, lack of motivation, anxiety, depression, insecurity, corticoid-induced skeletal muscle atrophy, recurrence of rejection, and reduction in cardiorespiratory performance of the transplanted patient justify the prescription of physical exercise. A number of physical conditioning programs have been described ${ }^{72,82-88}$. In 1983, Squires et al ${ }^{82}$ started a two-month supervised program six weeks following cardiac transplantation in two patients. The training was performed on a treadmill and bicycle three times per week for 30min using Borg's scale of perceived effort between 12 and 13. Kavanagh et al ${ }^{71}$ effected a program of walking and light running five times per week with sessions of 45 min at 60-70\% maximal $\mathrm{VO}_{2}$ and 14 on Borg's scale. The training lasted $16 \pm 7$ months. Ferraz and Arakaki ${ }^{87}$ established a supervised rehabilitation program with calisthenics on a stationary bicycle, short walks or runs and recreational games like adapted volleyball three times a week with sessions lasting $45 \mathrm{~min}$ at the $80 \%$ of anaerobic threshold and Borg's scale between 13 and 15. The program lasted on average 14 months. Romano et al ${ }^{86}$ trained transplanted subjects for 6 to 10 months and compared them with a group of untrained subjects. In the trained group, $\mathrm{VO}_{2}$ was raised by $85 \%$ (vs. $45 \%$ in the untrained group). In general, transplanted subjects should exercise three to five times a week at between 50 and $75 \% \mathrm{VO}_{2}$ and Borg's scale between 13 and 15. Innumerable benefits of posttransplantation physical conditioning have been reported: reduced heart rate and arterial pressure during rest, decreased heart rate, arterial pressure, ventilartory equivalent for oxygen, ventilatory equivalent for carbon dioxide in submaximal exercise; increased heart rate, systolic arterial pressure, $\mathrm{VO}_{2}$, pulmonary ventilation, and reduction in arterial diastolic pressure at peak exercise; increased aerobic threshold, retardation of lactate elevation during exercise, reduction in effort perception by the Borg scale ${ }^{72,82-87}$.

\section{References}

1. Hunt SA, Bristow MR, Kubo SH, O'Connel JB, Young JB. Task Force 8: Training in heart failure and transplantation. J Am Coll Cardiol 1995; 25: 29-31.

2. Kaye MP. The Registry of the International Society for Heart and Lung Transplantation: Tenth official report-1993. J Heart Lung Transplant 1993; 12: $541-8$.

3. Paris W, Woodbury A, Thompson S, et al. Returning to work after heart transplantation. J Heart Lung Transplant 1993; 12: 46-54

4. Salles AF, Carvalho AC, Almeida DR, et al. Avaliação funcional cardio respirató- ria durante o exercício em portadores de transplante cardíaco. Arq Bras Cardiol 1992; 59(supl. II): 156.

5. Salles AF, Carvalho AC, Almeida DR, et al. Cinética do consumo de oxigênio no exercício em indivíduos submetidos a transplante ortotópico de coração. Arq Bras Cardiol 1993; 61(supl. II): 99.

6. Salles AF. Cinética do consumo de oxigênio durante exercício submáximo em portadores de transplante cardíaco ortotópico. Tese de mestrado - EPM, 1994. 
7. Salles AF, Oliveira Filho JA, Barros Neto TL, et al. Respostas cardiorrespiratórias durante exercício em portadores de transplante cardíaco. Análise ergoespirométrica comparativa com indivíduos normais. Arq Bras Cardiol 1998; 70: 15-18.

8. Starling EH. —Apud: Valenti PF, Mazzei ES, Masnatta G. Medicina Interna. Vol.I. 7 ed. Barcelona: Marin, 1970: XVII.

9. Pope SE, Stinson EB, Daughters GT, Schroeder JS, Ingels NB, Alderman E. Exercise response of the denervated heart in long-term cardiac transplant recipients. Am J Cardiol 1980; 46: 213-8.

10. Savin WM, Haskell WL, Schroeder JS, Stinson EB. Cadiorespiratory responses of cardiac transplant patients to graded, symptom-limited exercise. Ciculation 1980; 62: 55-60.

11. Cerretelli P, Grassi B, Colombini A, Caru B, Marconi C. Gas exchange and metabolic transients in heart transplant recipients. Resp Physiology 1988; 74: 355-71.

12. Banner NR, Lloyd MH, Hamilton RD, Innes JA, Guz A, Yacoub MH. Cardiopulmonary response to dynamic exercise after heart and combined heart-lung transplantation. Br Heart J 1989; 61: 215-23.

13. Stevenson LW, Sietsema K, Tillisch JH, et al. Exercise capacity for survivors of cardiac transplantation or sustained medical therapy for stable failure. Circulation 1990; 81: 78-85.

14. MandakJS, DonchezLJ, Mull RL, Mancini DM. Serial assesment of exercise capacity post cardiac transplantation. Circulation 1993; 88(suppl.): I-591.

15. Quigg R, Salyer J, Mohanty PK, Simpson P. Impaired exercise capacity late after cardiac transplantation: Influence of chronotropic incompetence, hypertension, and calcium channel blockers. Am Heart J 1998; 136: 465-73.

16. Hidalgo R, Alegriá E, Castelló R, et al. Stress testing in patients one year after orthotopic cardiac transplantation. Angiology 1989; 40: 650-5.

17. Jensen RL, Yanowitz FG, Crapo RO. Exercise hemodynamics and oxygen delivery measurements using rebreathing techniques in heart transplant patients. Am J Cardiol 1991; 68: 129-33.

18. Marzo KP, Wilson JR, Mancini DM. Effects of cardiac transplantation on ventilatory response to execise. Am J Cardiol 1992; 69: 547-53.

19. Braith RW, Wood CE, Limacher MC, et al. Abnormal neuroendocrine responses during exercise in heart transplant recipients. Circulation 1992; 86: 1453-63.

20. Braith RW, Limacher MC, Staples ED, Pollock ML. Blood gas dynamics on the onset of exercise in heart transplant recipients. Chest 1993; 103: 1692-8.

21. Kao AC, Trigt PV, Shaeffer-McCall GS, et al. Central and peripheral limitations to upright exercise in untrained cardiac transplant recipients. Circulation 1994; 89: 2605-15.

22. Kao AC, Trigt PV, Shaeffer-McCall GS, et al. Allograft diastolic dysfunction and chronotropic incompetence limit cardiac output response to exercise two to six years after heart transplantation. J Heart Lung Transplant 1995; 14: 11-22.

23. Degré SGL, Niset GL, De Smet JM, Ibrahim T, Stoupel E. Cadiorespiratory response to early exercise testing after orthotopic cardiac transplantation. Am JCardiol 1987; 60: 926-28.

24. Meyer M, Cerretelli P, Cabrol C, Piiper J. $\mathrm{O}_{2}$ transport during exercise after cardiac transplantation. In: Erdmann W \& Bruley DP, ed,- Oxygen transport to tissue XIV. New York, Plenum Press, 1992; P: 491-6.

25. Paulus WJ, Brauzwaer JGF, Felice H, Kishan N, Welleus F. Deficient acceleration on the left ventricular relaxation during exercise after transplantation. Circulation 1992; 86: 1175-85.

26. Martin TW, Gaucher J, Pupa LE, Seaworth JF. Response to upright exercise after cardiac transplantation. Clin Cardiol 1994; 17: 292-300.

27. Horber FF, Hoppeler HS, Cheidegger JR, Gruning BE, Howald H, Frey FJ. Impact of physical training on the ultrastructure of midthigh muscle in normal subjects and in patients treated with glucocorticoids. J Clin Invest 1987; 79: 1181-90.

28. Massie B, Conway M, Rajagopalan B, et al. Skeletal muscle metabolism during exercise under ischemic conditions in congestive heart failure. Evidence for abnormalities unrelated to blood flow. Ciculation 1988; 78: 320-6.

29. Sinoway L, Minotti J, Davis D, et al. Delayed reversal of impaired vasodilation in congestive heart failure after heart transplantation. Am J Cardiol 1988; 61: 1076-9.

30. Ravenscraft AS, Gross CR, Kubo SH, et al. Pulmonary function after successful heart transplantation. Chest 1993; 103:54-8.

31. Beck W, Bernard CN, Schrive V. Heart rate after cardiac transplantation. Circulation 1968; 40: 437-45.

32. Campeau L, Pospisil L, Grondin P, Dyrda I, Lepage G. Cardiac catheterization findings at rest and after exercise in patients following cardiac transplantation. Am J Cardiol 1970; 25: 523-8.

33. Jose A, Collision D. The normal range and determinants of the intrinsic heart rate in man. Cadiovasc Res 1970; 4: 160-7.

34. Yusuf S, Theodoropoulos S, Dhalla N, Mathias C, Yacoub M. Effect of betablockade on dynamic exercise in human heart transplant recipients. Heart Transplant 1985; 4: 314-21

35. Marneffe M, Jacobs P, Haardt R, Englert M. Variations of normal sinus node function in relation to age: role of autonomic influence. Eur Heart J 1986; 7: 662-72.

36. Gaer J. Physiological consequences of complete cardiac denervation. British Journal of Hospital Medicine 1992; 48: 220-5.
37. Rudas L, Pflugfelder P, Menkis AH, Novick RJ, Mckenzie FN, Kostuck WJ. Evolution of heart rate responsiveness after orthotopic heart transplatation. Am J Cardiol 1991; 68: 232-6.

38. Degré S, Niset G, Coustry C. Apud: Degré SGLG. Are cardiac transplant recipients still suffering cardiac failure? Acta Cardiol 1993; XLVIII: 1-9.

39. Degré SGLG. Are cardiac transplant recipients still suffering cardiac failure? Acta Cardiol 1993; 48: 1-9.

40. Yusuf S, Theodoropoulos S, Mathias CJ, et al. Increased sensitivity of the denervated transplanted human heart to isoprenaline both before and after betaadrenergic blockade. Circulation 1987; 75: 696-704.

41. Blinks JR. Positive chronotropic effect of increasing right atrial pressure in the isolated mammalian heart. Am J Physiol 1956; 186: 299-303.

42. Shaver JA, Leon DF, Gray S, Leonard JJ, Bahnson HT. Hemodynamic observations after cardiac transplantation. N Engl J Med 1969; 281: 822-7.

43. Bexton RS, Milne JR, Cory-Pearce R, English TAH, Camm AJ. Effect of betablockade on exercise response after cardiac transplantation. Br Heart J 1983; 49: 584-8.

44. Scott CD, Dark JH, McComb JM. Evolution of the chronotropic response to exercise after cardiac transplantation. Am J Cardiol 1995; 76:1292-6.

45. Wharton J, Polak JM, Gordon L, et al. Immunohistochemical demonstration of human cardiac innervation before and after transplantation. Circ Res 1990; 66: 900-12.

46. Mohanty P, Thames M, Capehart J, Kawaguchi A, Ballon B, Lower R. Afferent reinnervation of the autotransplanted heart in dogs. J Am Coll Cardiol 1986: 7 : 414.

47. Burke MN, Mc Ginn AL, Homans DC, Christensen BV, Kubo SH, Wilson RF. Evidence for functional sympathetic reinnervation of left ventricle and coronary arteries after orthotopic cardiac transplantation in humans. Circulation 1995; 91: 72 .

48. Stark RP, Mc Ginn AL. Chest pain in cardiac- transplant recipients: evidence of sensory reinnervation after cardiac transplantation. N Engl J Med 1991; 324: 1791.

49. Kavanagh T, Yacoub MH. Exercise training in patients after heart transplantation. Annals Academy of Medicine 1992; 21:372-8.

50. Griepp RB, Stinson EB, Dong E, Clark DA, Shumway NE. Hemodynamic performance of the transplanted human heart. Surgery 1971; 70: 88-96.

51. Pflugfelder PW, Purves PD, Mckenzie FN, Kostuk WJ. Cardiac dynamics during supine exercise in cyclosporine-treated orthotopic heart transplant recipients: assesment by radionuclide angiography. J Am Coll Cardiol 1987; 10: 336-41.

52. Tischler MD, Lee RT, Plappert T, Mudge GH, Sutton MJ, Parker JD. Serial assesment of left ventricular function and mass after orthotopic heart transplantation: A 4 year longitudinal study. J Am Coll Cardiol 1992; 19: 60-6.

53. Bussières LM, Pflugfelder PW, Menkis AH, et al. Basis for aerobic impairment in patients after heart transplantation. J Heart Lung Transplant 1995; 14: 1073-80.

54. Savin WM, Schroeder JS, Haskell WL. Reponse of cardiac transplant recipients to static and dynamic exercise: A review. Heart Transplant 1983; 1: 72.

55. Mettauer B, Lampert E, Petitjean P, et al. Persistent exercise intolerance following cardiac tranplantation despite normal oxygen transport. Int J Sports Med 1996; 17: 277-86.

56. Klausen K, Andersen LB, Pelle I. Adaptive changes in work capacity training and detraining. Acta Physiol Scand 1981; 113: 9-16.

57. Chi MMY, Hintz CS, Coyle EF, et al. Effects of detraining on enzymes of energy metabolism in individual human muscle fibers. Am J Physiol 1983; 244: C276C87.

58. HorberFF, Scheidegger JR, Gruning BE, Frey FJ. Thigh muscle mass and function in patients treated with glucocorticoids. Eur J Clin Invest 1985; 15:302-07.

59. Ruff RL. Endocrine myopathies (hyper-and hipofunction of adrenal, thyroid, pituitary, and parathyroid glands and iatrogenic steroid myopathy). In: Engel AG, Banker BQ, eds. Myology. New York: Mc Graw-Hill, 1986: 1871-9.

60. Sullivan MJ, Green HJ, Cobb FR. Skeletal muscle biochemistry and histology in ambulatory patients with long-term heart failure. Circulation 1990; 81: 518-27.

61. Registry of the International Society of Heart Tranplantation. Transplantation around the world. J Heart Transplant 1986; 5: 1-88.

62. Bortolotto LA, Silva HB, Bocchi EA, Bellotti G, Stolf N, Jatene AD. Evolução a longo prazo e complicações da hipertensão arterial após transplante cardíaco. Arq Bras Cardiol 1997; 69: 317-21.

63. Schachter M. Cyclosporine A and hypertension. J Hypertension 1986; 6: 511-6.

64. Luke RG. Mechanism of cyclosporine-induced hypertension. Am J Hypertens 1989; 4: 468-71

65. Starling RC, Cody RJ. Cardiac transplant hypertension. Am J Cardiol 1990; 65 106-11.

66. Scott JP, Higenbottam TW, Hutter JA, Large S, Wallwork J. Effects of the immunosuppressant cyclosporine on the circulation of the heart transplant recipients. Am J Cardiol 1991; 67: 628-32.

67. Textor SC. De novo hypertension after liver transplantation. Hypertension 1993; 22: 257-67. 
68. Bocchi E, Vilas-Boas F, Bacal F, et al. Avaliação hemodinâmica durante exercício isotônico em pacientes submetidos a transplante cardíaco ortotópico. Arq Bras Cardiol 1994: 63: 7-12.

69. Killian K, Jones N. Respiratory muscle and dyspnea. Clin Chest Med 1988; 9 ; 237-48.

70. Mancini DM, Ferraro N, Nazzaro D, Chance B, Wilson J. Demonstration of respiratory muscle deoxygenation during exercise in patients with heart failure using near-infrared spectroscopy. J Am Coll Cardiol 1991b; 18: 492-8.

71. Kavanagh T, Yacoub MH, Mertens DJ, Kennedy J, Cambell RB, Sawyer P. Cardiorespiratory responses to exercise training after orthotopic cardiac transplantation. Circulation 1988; 77: 162-71.

72. Schuler S, Thomas D, Hetzer R. Cyclosporine A - related nephrotoxicity after cardiac transplantation: The role of plasma renin activity. Transplant Proc 1987; 19 : 3998-4001.

73. Scherrer U, Vissing S, Morgan B, et al. Cyclosporine- induced sympathetic activation and hypertension after heart transplantation. N Engl J Med 1990; 323 : 693-9.

74. Drieu L, Rainfray M,CabrolC, Ardaillou R. Vasopressin, aldosterone, and renin responses to volume depletion in heart transplant recipients. Clin Sci 1986; 70: 233-41

75. Drexler H, Reide U, Munzel T, Konig H, Funke E, Just H. Alterations of skeletal muscle in chronic heart failure. Circulation 1992; 85: 1751-9.

76. Smart FW, Ballantyne CM, Cocanougher B, et al. Insensitivity of noninvasive tests heart coronary artery vasculopathy after heart transplantation. Am J Cardio 1991; 67: 243-7.

77. Ehrman JK, Keteyian SJ, Levine AB, Rhoads KL, Elder LR, Levine TB, Stein PD. Exercise stress tests after cardiac transplantation. Am J Cardiol 1993; 71: 1372-3.
78. ACC/AHA Task Force Report-Guidelines for clinical use of cardiac radionuclide imaging. J Am Coll Cardiol 1995; 25: 521-47.

79. Rodney RA, Johnson LL. Myocardial perfusion scintigraphy to assess heart transplant vasculopathy. J Heart Lung Transplant 1992; 11: 574-8.

80. AHA Medical/Scientific Statement. Exercise Standars. Ciculation 1995; 91 : 580-615.

81. Gullestad L, Myers J, Noddeland H, et al. Influence of the exercise protocol on hemodynamic, gas exchange and neurohormonal responses to exercise in heart transplant recipients. J. Heart Lung Transplant 1996; 15: 304-13.

82. Squires RW, ArthurPR, Gau GT, Muri A, Lambert WB. Exercise after cardiac transplantation: A report of two cases. J Cardiopulmonary Rehab 1983; 3: 570-4.

83. Degre S, Miset G, Desmet JM, et al. Effects du trainement physique sur le coeur human denervé après transplantation cardiaque orthotopique. Ann Cardiol Angeiol 1986; 35: 147-9.

84. Niset G, Counstry-Degre C, Degre S. Psychosocial and physical rehabilitation after heart transplantation. 1 year follow-up. Cardiology 1988; 75: 311-7.

85. Keteyian S, Ehrman J, Fedel F, Rhoads K. Rehabilitation following cardiac heart transplantation. Med Sci Sports Exercise 1989; 21: 555.

86. Romano A, Stolf N, Bocchi E, Bellotti G. Contribuição do treinamento físico após transplante cardíaco. In: Yazbek Jr P, Battistella LR. Condicionamento Físico do Atleta ao Transplantado. São Paulo: Sarvier, 1994

87. Ferraz AS, Arakaki H. Atividade física e qualidade de vida após transplante cardíaco. Rev Soc Cardiol ESP 1995; 6: 670-8.

88. Lampert E, Mettauer B, Hoppeler H, Charloux A, Charpentier A, Lonsdorfer J. Skeletal muscle response to short endurance training in heart transplant recipients. J Am Coll Cardiol 1998; 32: 420-6. 